\title{
CULTURAL LITERACY: USING WORLDVIEWS BEHIND THE CULTURAL EVENTS FOR HUMANIZING THE STUDENTS
}

\author{
Sigit Haryanto \\ FKIP - Universitas Muhammadiyah Surakarta \\ Sh288@ums.ac.id
}

\begin{abstract}
Javanese society has many cultural events, like Sekaten, Suran, Bakdan, and Sadranan. In each cultural event may have two or threeworldviews that are able to be used as media for humanizing the students. A worldview is the set of beliefs about fundamental aspects of reality that ground and influence all one's perceiving, thinking, knowing, and doing. Humanizing is a process of making the member of society understanding and doing benefit values. Based on the ethnography study done in Boyolali Central Java 2017, Sadranan, as a focus of this article, has three worldviews, namely: honor, togetherness, and alms/charity. Honor is meant to respect the departed spirit: parents, grandfather and ma by praying to God. Togetherness is realized bybesikmakam(cleaning the grass in the tomb) kondangan(praying together). Alms/charity is performed by bringing tenong (a place contains foods) to the tomb then given to the others. The three worldviews should be taught to the students as successors of acknowledged culture.
\end{abstract}

Keywords: cultural event, worldviews, culture literacy, Sadranan

\section{INTRODUCTION}

Education for All Global Monitoring Report (2006) mentions that the most common understanding of literacy is that it is a set of tangible skills - particularly the cognitive skills of reading and writing). Then, in the development, literacy means the competency to use printed or digital media (Markhamah, 2017). However, in cultural literacy, it is defined as the ability to understand and participate fluently in a given culture (Hirsch in https://en.wikipedia.org/wiki/Cultural_literacy).Cultural Literacy in Europe: Second Biennial Conference discusses that cultural literacy isan ability to view the social and cultural phenomena that shape our lives bodies of knowledge, fields of social action, individuals or groups, and of course cultural artifacts - as being essentially readable (http://cleurope.eu/cle2017/).

Our lives are commonly shaped by two manners, surface and deep culture, surface is in signs or symbols. Deep is thought or ideas. Something that are seeable really is signs or symbols. Signs or symbols are surface. However, understanding the essencial content of the culture is understanding the worldviews or deep culture, local wisdom, and mindset (Abdullah, 2016). Worldviews of society are able to be traced by symbols behind the cultural events. Or it is similarized with the following term 'talking about culture is the same as talking about symbols' because symbols are media of expressing ideas or reality of life (Muslich,2004).

Culture and and society are two diciplines that can not be separated. Society produces language, art, society's rules, customs and traditions, and etc. In each element, especially in customs and traditions worldviews will be the motor of the cultural events. Worldviews encompasses everything that is important to an individual (Vidal, 2008). Worldviews are the set of beliefs about fundamental aspects of reality that ground and influence all one's perceiving, thinking, knowing, and doing. The term worldview is used to refer to the common concept of reality shared by a particular group of people, usually referred to as a culture, or an ethnic group.

Worldviews are values that are trusted and selectedcomprehensively by society (Koentjaraningrat1984). With worldviews, people are able to live harmonizely in it.They use it as a guidelife. Dignity and humanity are determined by how tightly the member of society holds and practices them.Humans become humanize when they have awareness and appreciation of values believed together in society. 
The awareness and appreciation of culture values are practiced by the Cepogonese in Sadranan event. They still believe that Sadranan is part of thesocial needs and individual needs.Sadrananis an event that deals withRuwah month (Javanese calender), month before Pasa (fasting month for moeslems). The surface culture of Sadranan is seeable in the followings figures.

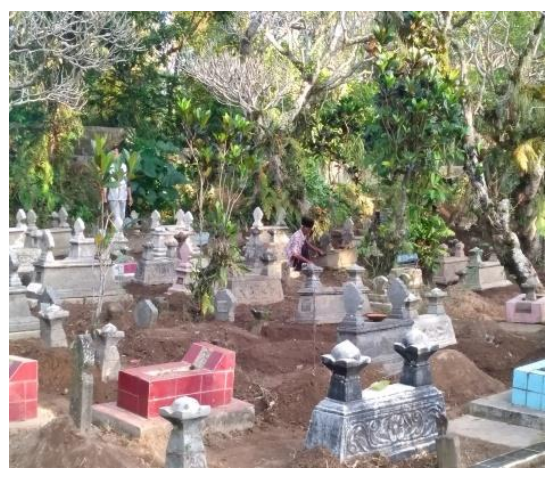

Figure 1. Activity in the TombFigure

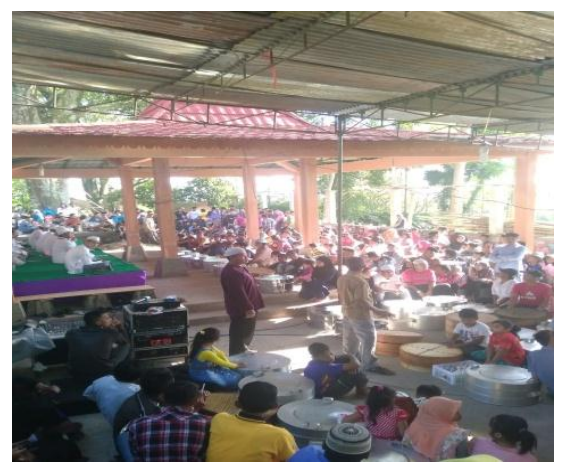

2.Activity of praying

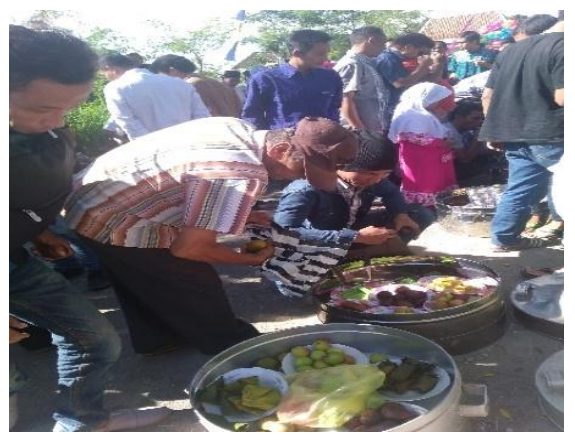

Figure 3. Foods for others

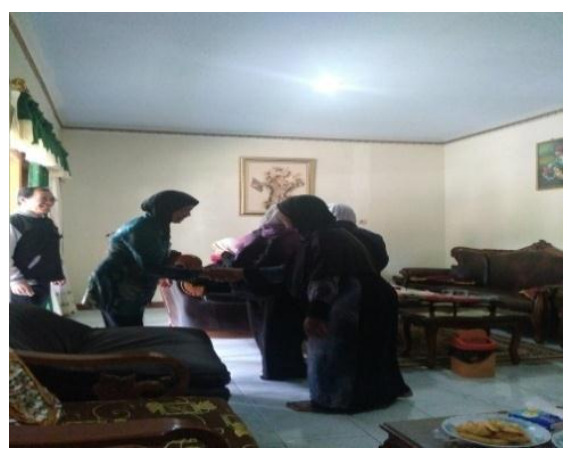

Figure 4. Greeting the visitors

Attading the grave is usually twice. First is for pulling out the grass or cleaning the derty surround it (Figure 1). The second attandance (Figure 2) is praying together with being led by Kyai (spiritual in religion). After that the society opens his tenong then pleased visitors to take it (Figure 3). Friends, families, or others visit the person who celebrate Sadrananin that day. It is lasting from morning to evening. Those are activities and artefact of Sadranan.

Finding the core of culture or deep culture should be proceeded because the soul ofSadranan is not on the surface. This short article tries explaining the deep culture or worldviews of Sadranan by doing etnographic research.

\section{RESEARCH METHOD}

Etnography method is selected to dig the worldviews of Sadranan in Cepogo Boyolali Central Java. Data were collected by observation, in depth interviews, and documentation that conducted at $13-15$ Mei 2017. The collected data were analysed by using Spreadly theory, that is DOTACOMTE, domain, taxconomy, componencial, and theme (Spradley, 1979, 2007; Santosa, 2017), then the results of data analysis were presented descriptively.

\section{FINDING AND DISCUSSION}

Worldviews found in Sadranan are summarized into three: honor, togetherness, and alms/charity. 


\section{HONOR}

Giving honor to the parent is obligated in Javanese culture. Honor is given when the parent is still alive and also when they have died. In Javanese, it is called bektimarangwongtua (obey to the parent) (Mulder, 1985). Sadranan with besikmakam (cleaning the dirty) and ndongakke (praying) is a symbol of respect to parent. Chosim, first informant, said that Sadrananis a means of obeying to parent by visiting their tomb and praying there. He also added that bektimarangwongtua is the same as BirrulWalidain (Islamic worldview). The physical forms of respect are symbolized in the following figures.

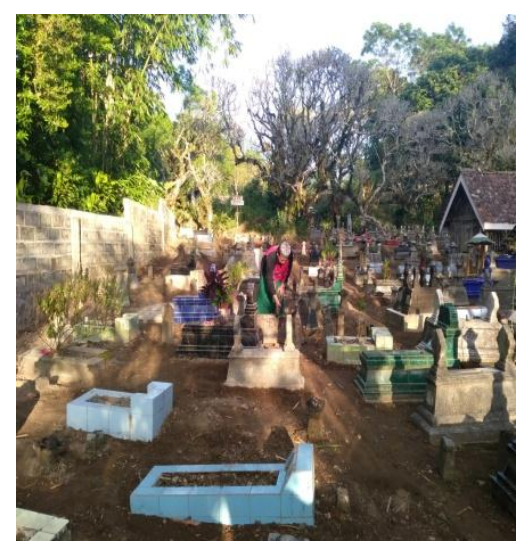

Figure 5. Pulling out the grass

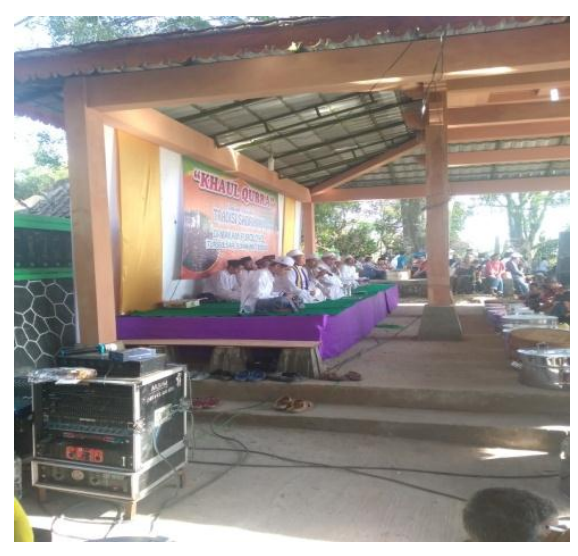

Figure 6. Praying together

\section{TOGETHERNESS}

Javanese has worldview "rukunagawesantosa" (togetherness makes powerfulness). The surface culture of that is usually realized by working together (kerjabakti), doing social job together, and so on (Anam, 2017). Togetherness is also acted by Cepogonese people when they come in a group to the tomb and sit together orderly, as described in the picture 7 and 8 .

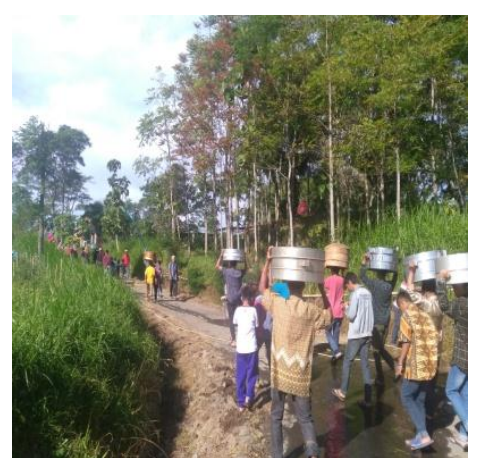

Figure 7. Walking together

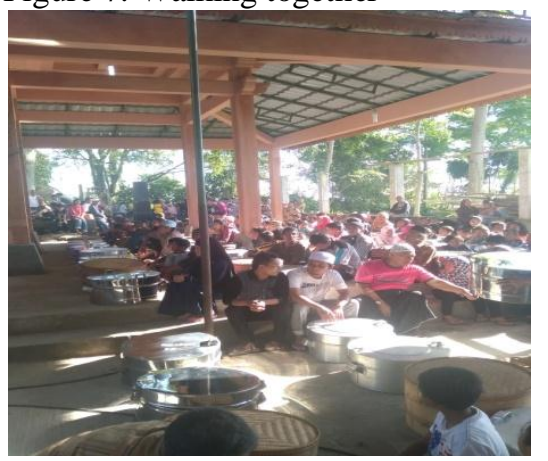

Figure 8. Sit patiently

\section{ALMS/CHARITY}

Mr. Suparno as a second informant said that "makananyang kami bawakemakamitudiniatkanuntuksodakoh" (foods that you we bring to the tomb are intendedas alms). Figure 9 and 10 below show how the people bring and give the foods to other. Other informant, Suyamto, said that "sodakoh diajarkan dalam acara Sadranan ini" (charity is thaught is Sadranan). The society believes that by "sodakoh" sustenace will be run well. 


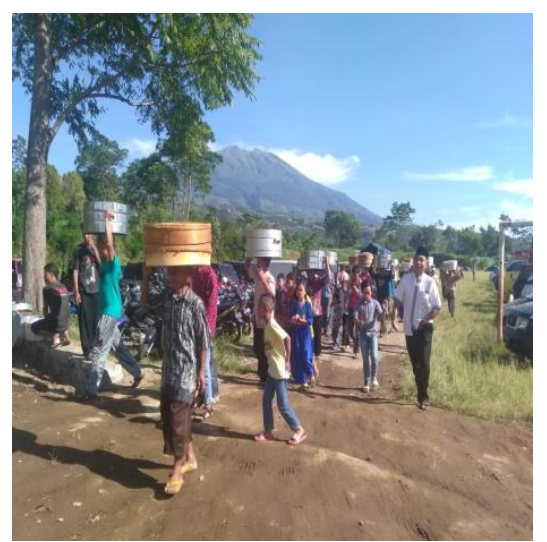

Figure 9. People bring the foods

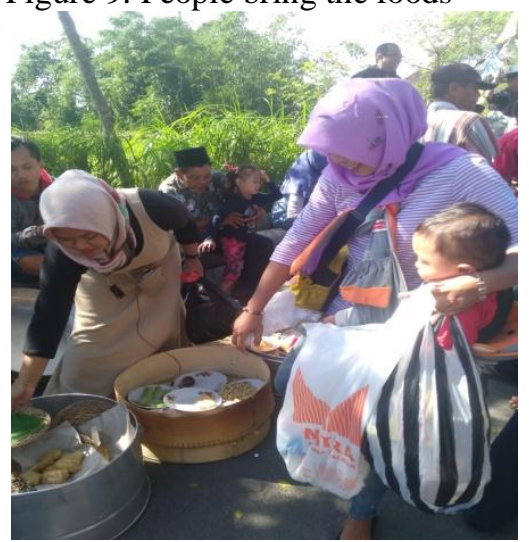

Figure 10. Giving the foods to others

\section{CONCLUSION}

To understand the deep culture really is not difficult. It can be found by understanding the activities and artifacts. From that it will be known the worldviews of a certain society performed through cultural event. From analysis and discussion, it is known that Sadranan has three worldviews, those are, honor, togetherness, and alms/charity. The realization of honor to the death is figured by attending the tomb. Togetherness is done by praying together. Alms/charity is performed by giving foods to others.

\section{References}

Abdullah. Wakit. 2016. Ethnolinguistic Study of Local Wisdom in Ex-Residency of Surakarta. JurnalHumaniora. Vol. 28. No. 3, 2016.

Anam, Choirul. 2017. TradisiSambatandanNyadran di DusunSuruhan. JurnalSabda Vol. 12. No. 1. Juni 2017.

Cultural Literacy in Europe: Second Biennial

Conference, Warsaw 10-12 May 2017 (http://cleurope.eu/cle2017/).

Hirsh, E.D

https://en.wikipedia.org/wiki/Cultural_literacy).

Koentjaraningrat. 1984. KebudayaanJawa. Jakarta: BalaiPustaka.

Markhamah, 2017. Preface in Proceedings of

International Conference on Language, Literature, and Teaching Held in UMS 4-5 April 2017.

Magnis-Suseno, Franz. 2001.EtikaJawa. Jakarta: GramediaPustakaUtama.

Muslich, M. 2004. Panduan Hidup dan Simbol-Simbol

dalam Budaya Jawa. Millah. Vol.3. No. 2004.

Mulder, Niels. 1985. PribadidanMasyarakat di Jawa. Jakarta: Sinarharapan.

Santosa, Riyadi.

2017.

MetodePenelitianKualitatifKebahasaan. Surakarta:

UniversitasSebelas

Maret Press.

Spradley, James P.2007. MetodeEtnografi. Yogyakarta: Tiara budayaYogya.

Spradley, James P. 1979. The Ethnographic Interview. USA: Holt, Rinehart and Winston.

Vidal, Clement. 2008. What is a Worldview?

http://clement.vidal.philosophons.com 